\title{
Assessment of Feedstocks and Technologies for Advanced Biofuel Production
}

\author{
Elena Cerruti $^{1}$, Francesca Di Gruttola ${ }^{1}$, Giancarlo Lauro $^{2}$, Teresa Dina Valentini $^{2}$, Paolo \\ Fiaschi $^{2}$, Roberto Sorrenti ${ }^{3}$, Domenico Borello ${ }^{1}$ \\ ${ }^{1}$ Sapienza Università di Roma, Dipartimento di Ingegneria Meccanica e Aerospaziale, via Eudossiana \\ 18, 00184, Roma (Italy) \\ ${ }^{2}$ ENI Refining \& Marketing, Piazzale Enrico Mattei 1, 00144 Roma (Italy) \\ ${ }^{3}$ ELIS, Via Sandro Sandri, 81, 00159 Roma (Italy)
}

\begin{abstract}
The present contribution deals with a comprehensive analysis of the available feedstocks and the appropriate technologies to produce advanced biofuels. The analysis is focused on the EU countries, since they adopted policy measures able to promote advanced biofuels as a strategic solution for a competitive and sustainable transport sector. In this regard, four classes of feedstocks have been taken into account: wastes, vegetable oils, agricultural and forestry residues. Their availability is studied with the aim to respect the European targets in terms of emissions without neglecting possible negative impacts on environment and biodiversity. A metric for the classification of the different solutions is proposed on the basis of feedstocks availability, technology readiness levels (TRL), quality of the produced biofuel as well as feedstock and production costs. It is possible to conclude that, even if the several interesting alternatives currently available have a high ranking in the proposed metric and must be taken in consideration, green diesel is today the most convenient solution for producing advanced biofuel without risks of technological failures and feedstocks shortage. This analysis can provide insights to encourage the development of advanced biofuels in EU, especially for some of the Member States as Germany, France and Italy.
\end{abstract}

\section{Introduction}

Biofuels are liquid or gaseous transport fuels such as biodiesel and bioethanol which are produced from biomass. Biofuels represent a sustainable alternative to fossil fuels in many market segments (including the transport sector), helping to reduce greenhouse gas (GHG) emissions and increase the EU's security of supply. Specific prescriptions are present in the revised Renewable Energy Directive (RED II) [1] for promoting the use of biofuels (minimum $14 \%$ of liquid fuels by 2030). The Directive indicates that such limits can be increased during biennial revision with a specific action scheduled in 2021. Furthermore, in 2018, $\mathrm{CO}_{2}$ emissions from transport (including international aviation but excluding international shipping) were still $28 \%$ above 1990 levels. Therefore, emissions will need to fall by two-thirds by 2050 in order to meet the $60 \%$ greenhouse gas emission reduction target of the EU 2011 Transport White Paper. However, while biofuels are important in helping the EU meeting its 
GHG reductions targets, the production of biofuels requires cropland that was traditionally used to grow food or feed supplies. To take in account these aspects, the Directive indicates specific targets related to the production of advanced biofuels (Annex IX of the RED Directive) from secondary (advanced) biomass $(0.2 \%$ at $2022,1 \%$ at 2025 and $3.5 \%$ at 2030$)$. In December 2019, in Italy, a National Plan for Energy and Climate (PNIEC - Piano Nazionale Integrato Energia e Clima [2]) was released. In the PNIEC, the ambitious 2030 targets specified in the RED II were further increased, fixing a threshold value of $8 \%$ of advanced biofuel in Italy (being $22.4 \%$ the total share of biofuels). If realized, these ambitious targets can have a real impact on overall emissions.

Unfortunately, a recent International Energy Agency (IEA) report [3] showed that the growth rate of biofuel use is not sufficient to reach the targets of the 2030 Sustainable Development Scenario (SDS) as shown in Figure 1-left. As for EU, IEA calculated that the annual average growth in the period 2019-2025 was equal to $0.5 \%$, while the expected rate to meet the 2030 SDS objective is equal to $9 \%$. This is confirmed by the chart shown in Figure 1-right.
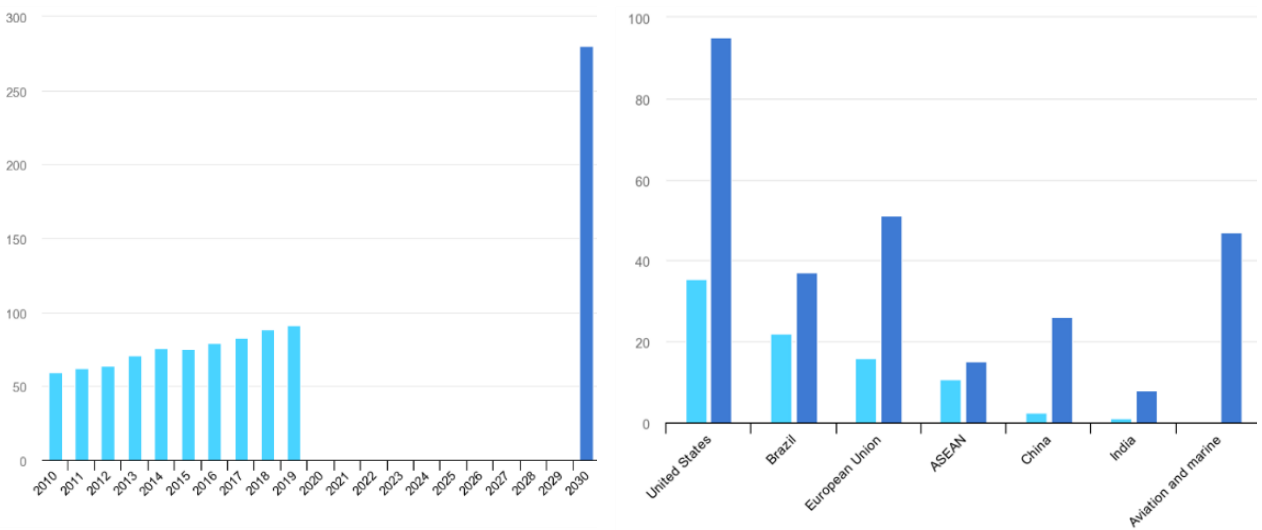

Figure 1. Current trends in biofuel production (in Mtoe): left - worldwide annual growth; right - actual production (light blue) and 2030 SDS consumption (deep blue) in the most relevant markets; (IEA data).

However, the production of a large quantity of biofuel is a very challenging objective, especially because extensive use of soil for growth of energy crops can lead to Indirect Land Use Change (ILUC) pushing to eliminate forestry for crop cultivation, eventually leading to a greater rate of GHG emissions.

It is then very important to carry out an extensive assessment of the potential of advanced biofuels produced by using wastes or secondary biomass following an idea of sustainability (no use of energy crops) and circularity (second use of wastes and other residuals).

Such assessment requires to determine the best solution(s) for the advanced biofuels, taking into account the feedstock availability, the expected trend in the next years as well as the readiness of the conversion technologies. This is the main objective of the present contribution, where this analysis was carried out focusing on EU.

In the next paragraph, the availability of the feedstocks is examined and prediction for the near-term period are drawn. Then, the available technologies are assessed on the basis of their Technology Readiness Level (TRL), representing a widely accepted standard for ranking the maturity of the different solutions [4]. Finally, a possible metric for ranking the different solution is proposed in order to detect the most appropriate solution(s) for advanced biofuel production. Some conclusion closes the paper. 


\section{Analysis of the available feedstocks for advanced biofuels}

According to the Renewable Energy Directive (RED II) Annex IX, part A, the feedstocks for the advanced biofuels production may be usefully divided in three main categories: wastes, , crop and forestry residues. Nevertheless, also vegetable oils availability is here considered with the aim to be compared with the advanced feedstocks availability. This assessment has been carried out within European territory, and open databases as FAOSTAT and EUROSTAT relating to the total production quantity, have been advantageously used. However, such data should be carefully analyzed in order to avoid negative impacts on environment (e.g. GHG emissions related to transport of the feedstocks for long distances or agricultural residuals used to improve soil fertility) or to neglect the partial unavailability due to other competitive uses, as illustrated in [5]. The EU countries with the most abundant availability of feedstocks eligible for the production of both advanced and traditional biofuels are France and Germany as reported in Figure 2.

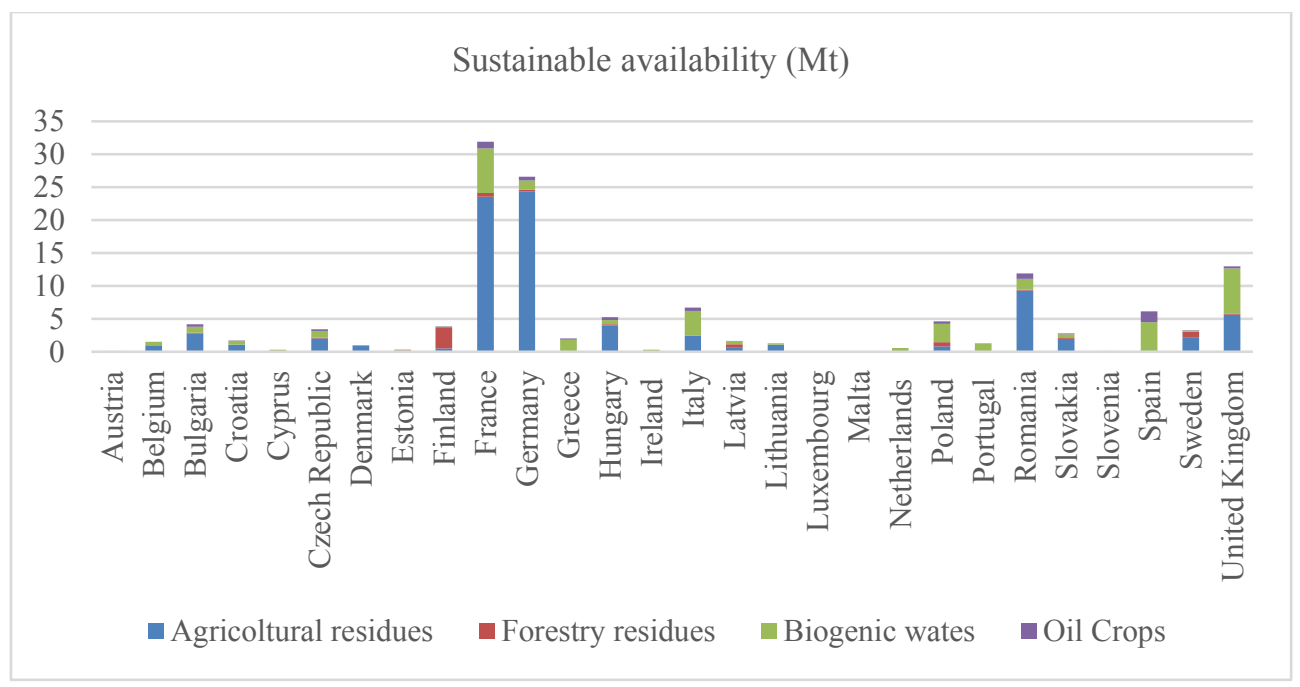

Figure 2. Current total sustainable availability of wastes, vegetable oils, crop and forestry residues.

\subsection{Wastes availability}

Production data on wastes are obtained from EUROSTAT database [6]. Both hazardous and non-hazardous dry wastes, disposed in landfills, released into water bodies or incinerated without any energy recovery, are held to be available to produce sustainably advanced biofuels. In particular, they belong to the disposal operations from D1 to D7, D10 and D12 as reported in [7]. In Table 1, several items are considered to maximize the sustainable feedstocks availability. However, over the years, it is expected that both production of wastes and number of landfills will decrease due to National and European directives and an increasing number of incinerated wastes will be subject to energy recovery [5]. 
Table 1. Sustainable availability of wastes in million tonnes per year in EU.

\begin{tabular}{|c|c|c|c|c|c|c|c|c|c|}
\hline $\begin{array}{c}\text { Wastes } \\
\text { [EURO- } \\
\text { STAT] }\end{array}$ & $\begin{array}{c}\text { Paper } \\
\text { and } \\
\text { card- } \\
\text { board } \\
\text { wastes }\end{array}$ & $\begin{array}{c}\text { Wood } \\
\text { wastes }\end{array}$ & $\begin{array}{c}\text { Animal } \\
\text { and } \\
\text { mixed } \\
\text { food } \\
\text { waste }\end{array}$ & $\begin{array}{c}\text { Vegetal } \\
\text { wastes }\end{array}$ & $\begin{array}{c}\text { Animal } \\
\text { faeces, } \\
\text { urine and } \\
\text { manure }\end{array}$ & $\begin{array}{c}\text { Household } \\
\text { and similar } \\
\text { wastes }\end{array}$ & $\begin{array}{c}\text { Sorting } \\
\text { residues }\end{array}$ & $\begin{array}{c}\text { Common } \\
\text { sludges }\end{array}$ & $\begin{array}{c}\text { Sustainable } \\
\text { Availability }\end{array}$ \\
\hline Total EU & 0.092 & 1.257 & 0.508 & 0.351 & 0.530 & 19.775 & 9.253 & 3.096 & 34.86 \\
\hline
\end{tabular}

\subsection{Vegetable oils availability}

According to FAOSTAT [8], the main oil crops produced in 2018 in EU derive from olives, rapeseed, soybeans and sunflower seed. Their uses are destinated mainly to the food industry with percentage ranging between 80-90\%, depending on the oil type as reported in [9]. Therefore, only the other $10-20 \%$ can be used as raw material in the chemical industry. The same author affirms that this fraction consists in a percentage of $5 \%$ of crude plant oil, of free fatty acids. These latter are generally involved in the production of biodiesel [10]. According to [9], Table 2 shows the oil crops availability considering the conservative hypothesis that the $85 \%$ of oil serves the food market and the remaining part may be used in the chemical industry to produce eventually advanced biofuels.

Table 2. Sustainable availability of vegetable oils in million tonnes per year in EU.

\begin{tabular}{|c|c|c|c|c|}
\hline $\begin{array}{c}\text { Oil crops [FAOSTAT, } \\
\text { 2018] }\end{array}$ & $\begin{array}{c}\text { Production Quantity } \\
\text { [million tonnes] }\end{array}$ & $\begin{array}{c}\text { Food Industry } \\
\text { [million tonnes] }\end{array}$ & $\begin{array}{c}\text { Chemical Industry } \\
\text { [million tonnes] }\end{array}$ & $\begin{array}{c}\text { Free Fatty Acids } \\
\text { [million tonnes] }\end{array}$ \\
\hline Rlives & 13.70 & 11.65 & 2.06 & 0.10 \\
\hline Soybeanseed & 25.49 & 21.67 & 3.82 & 0.19 \\
\hline Sunflower seed & 12.06 & 10.25 & 1.81 & 0.09 \\
\hline Total & 38.43 & 32.66 & 5.76 & 0.29 \\
\hline
\end{tabular}

The vegetable oils availability is clearly very low, which makes vegetable oils out of the advanced biofuels business.

\subsection{Crop residues availability}

The sustainable availability of agricultural residues in Table 3 can be estimated from FAOSTAT [9] through the following expression:

$$
C S A=C R-Z-U_{1}-U_{2}
$$

Where, CSA represents the sustainable availability of crops, calculated by subtracting the amount of agricultural residues retained for soil conservation $(Z)$ and the amount destined for other uses $\left(U_{1}\right.$ and $\left.U_{2}\right)$ from the total residues production $(C R)$. Z, $U_{1}$ and $U_{2}$ are considered constant quantities for the entire period as reported in [5].

Nevertheless, the total crop residues are estimated from the total production $(Y)$ through the residue-to-production ratio or $R P R$ (whose values are reported in [11]) as expressed below:

$$
C R=Y \times R P R
$$

The total agricultural production data are defined in FAOSTAT and calculated on average in the period between 2014 and 2018 for the following twelve crops: barley, oats, olives, corn, 
wheat, soybeans, rapeseed, sunflower, sugar beet, rice, rye, triticale. The reason why, part of the agricultural residues is left on the production site is related to the preservation of the soil quality $(Z)$ in order to avoid unacceptable levels of erosion.

The quantity already intended for other uses must also be subtracted from the total above ground production. It includes that part destined for heat and power and the other part used for livestock bedding, cultivation of mushrooms and horticulture. For agricultural residues, the greatest sustainable availability is found in France and Germany, countries with the most developed agricultural sector as shown in Figure 2. Other countries such as Austria and Greece already commit all agricultural residues for other uses, thus not having an available quantity to be involved in the production of advanced biofuel.

Table 3. Sustainable availability of crop residues, in million tonnes per year in EU.

\begin{tabular}{|c|c|c|c|c|c|}
\hline $\begin{array}{c}\text { Crops production } \\
\text { [FAOSTAT] }\end{array}$ & $\begin{array}{c}\text { Agricultural resi- } \\
\text { dues production }\end{array}$ & $\begin{array}{c}\text { Residual retention } \\
\text { for soil quality }\end{array}$ & Heat, Power & Other uses & $\begin{array}{c}\text { Sustainable } \\
\text { availability }\end{array}$ \\
\hline Total EU & 335.5 & 196.1 & 26.93 & 28.4 & 84.6 \\
\hline
\end{tabular}

\subsection{Forestry residues availability}

Similarly, the availability of the forestry residues (Table 4) can be obtained by the following expression:

$$
F S A=F R-Z-U_{1}
$$

FSA indicates the sustainable availability of residues from forestry, $Z$ is the amount of forestry residues to be left on the production site to ensure biodiversity in the future and $U_{1}$, the residues already destined for other uses (e.g. heating and energy). $\mathrm{Z}$ and $U_{1}$ are consideredconstant quantities for the entire period as reported in [5]. The forestry residues production is obtained by multiplying the data relating to the total production of round wood $(X)$ from the FAOSTAT database [12] by a different residue-to-production ratio $(R P R)$, depending on whether it is conifers, non-conifers or whether it derives from Nordic or other European countries [1]. The correlation between forestry residues and total production is shown in the following expression:

$$
\boldsymbol{F R}=\boldsymbol{X} \times \boldsymbol{R P R}
$$

The European countries with the highest sustainable availability are Sweden and Finland. Other countries such as Italy and Holland use all the produced residues for heating and energy as demonstrated in Figure 2.

Table 4. Sustainable availability of forestry residues in million tonnes per year in EU.

\begin{tabular}{|c|c|c|c|c|}
\hline $\begin{array}{c}\text { Forestry pro- } \\
\text { duction [FAO- } \\
\text { STAT] }\end{array}$ & $\begin{array}{c}\text { Forestry residues } \\
\text { production }\end{array}$ & $\begin{array}{c}\text { Residual retention for } \\
\text { the soil quality }\end{array}$ & Heat and Power & Sustainable Availability \\
\hline Total EU & 67.59 & 46.06 & 14.18 & 7.35 \\
\hline
\end{tabular}

\section{Technological maturity level for advanced biofuels}

The production of advanced biofuels through innovative industrial technologies is a critical point of the bioeconomic value chain. In fact, this latter relates the primary sector with biorefinery and manufacturing one, as well as the marketing sector, through which biofuels 
and eventually by-products arrive to the end-users. The technological processes currently available to convert second generation biomasses, can be divided in four main classes: thermal, thermochemical, biochemical and chemical conversion processes, of which, the last three are the most widespread and strictly used to produce biofuels for the transport sector.

In this study, several appropriate technologies are being analyzed with the aim to identify their potentiality in terms of maturity level. In this respect, the advanced biofuels pathways may be defined by technology readiness level (TRL). There are nine levels to assess the maturity of a technology: TRL 1 is the lowest and TRL 9 represents the fully maturity.

Hydrotreated Vegetable Oils (HVO) or Hydroprocessed Esters and Fatty Acids (HEFA), Transesterification and Bio-Derived synthetic paraffinic kerosene (Bio-SPK) belong to the chemical conversion pathway. All of them can process vegetable or algal oils and animal fats to get products in the biodiesel fuel range or synthetic kerosene, used for transport and aviation sector respectively. As described in [14], HVO is a mature technology and already integrated in some existing oil refineries to co-process oil crops with fossil streams. For the same reasons, [15] assigns TRL of 9 to both HVO and HEFA technologies. Transesterification is a competitive and currently in operation technology too. However, if algal oils are used as feedstocks, [16] shows their conversion through transesterification, is situated in a range from TRL 2 to 4-5. As a matter of fact, there are not developed industrial plants yet, but just advanced testing labs. Bio-SPK is a promising new solution for the global aviation industry, since its main product, named green jet fuel, has identical properties to jet fuel [17]. As appears from [18], Bio-SPK is under assessment for commercial production (TRL 8).

In the biochemical conversion processes, alcohol fermentation, anaerobic digestion and syngas fermentation are included. These technologies are characterized by different feedstocks. Alcohol fermentation converts sugars and starches from agricultural crops in order to obtain conventional or first-generation ethanol used as transportation fuel for gasoline engine [15]. To produce advanced (or second-generation) ethanol, lignocellulosic residues should be used. The different feedstocks play a significative role in the TRL assessment. In fact, [15] distinguishes the two biofuels, conventional and cellulosic (or advanced) ethanol, by attributing them a TRL 9 and 7 respectively. Generally, TRL 7 technologies, as that for advanced ethanol production, are demonstration prototypes and then not yet fully commercial. Instead, anaerobic digestion is a widely used process to get mainly biomethane with a TRL of 9. Its high technological maturity is due to a demonstrated use on a large variety of available feedstocks such as organic waste fraction, industrial wastes, sewage and manure sludge including energy crops and crop residues [14]. Syngas Fermentation is an innovative process to produce ethanol. However further technological improvements are needed to increase its maturity level. This is also the reason why its TRL is limited to 6-7 as indicated in [19].

In the range of thermochemical conversion processes, thermal gasification and pyrolysis are widely used. During the gasification, both gaseous and liquid fuel can be produced from wastes, forestry and agricultural residues. The biomethane and the synthetic natural gas (SNG) is obtained via gasification with TRL 7, higher than the liquid fuel from lignocelluloses, whose technology has TRL 6. Similarly, pyrolysis is also a technology demonstrated in an industrially relevant environment with TRL 6. 
In addition, Fischer-Tropsch synthesis (FTS) and Fischer-Tropsch synthetic paraffinic kerosene (FT-SPK) must be considered. Both these biochemical technologies may be integrated at the thermochemical pathway with the aim to convert syngas in drop-in fuel and green jet fuel respectively. In recent years, Fischer-Tropsch processes have reached a higher maturity. [18] affirms FTS TRL is ranging between 5-9, while [20] defines FT-SPK with TRL of 6-8. An overview of the mentioned TRL analysis is found in Table 5.

Table 5. Assessment of the technological readiness level (TRL) for each mentioned technology.

\begin{tabular}{|c|c|c|}
\hline Available Technology & TRL & Status \\
\hline $\begin{array}{c}\text { HVO or HEFA } \\
{[15]}\end{array}$ & 9 & Commercial \\
\hline $\begin{array}{c}\text { Anaerobic Digestion } \\
{[15]}\end{array}$ & 9 & Commercial \\
\hline $\begin{array}{c}\text { Fermentation } \\
\text { for conventional ethanol } \\
{[15]}\end{array}$ & 9 & Commercial \\
\hline $\begin{array}{c}\text { Fermentation } \\
\text { for cellulosic ethanol } \\
{[15]}\end{array}$ & 7 & Demonstration \\
\hline $\begin{array}{c}\text { Syngas Fermentation } \\
{[19]}\end{array}$ & $6-7$ & Demonstration \\
\hline $\begin{array}{c}\text { Thermal gasification } \\
\text { for biomethane } \\
{[15]}\end{array}$ & 7 & Demonstration \\
\hline $\begin{array}{c}\text { Thermal gasification } \\
\text { for biomass to liquid (BTL) } \\
{[15]}\end{array}$ & 6 & Demonstration \\
\hline $\begin{array}{c}\text { Pyrolysis } \\
{[15]}\end{array}$ & 6 & Demonstration \\
\hline $\begin{array}{c}\text { Transesterification } \\
\text { from vegetable oil } \\
{[23]}\end{array}$ & 9 & Commercial \\
\hline $\begin{array}{c}\text { Transesterification } \\
\text { from algal oil } \\
{[16]}\end{array}$ & 2 a $4-5$ & Research-Pilot \\
\hline $\begin{array}{l}\text { FTS } \\
{[21]}\end{array}$ & $5-9$ & Pilot-Commercial \\
\hline $\begin{array}{c}\text { FT-SPK } \\
{[20]}\end{array}$ & $6-8$ & Demonstration-First-of-a-kind commercial \\
\hline $\begin{array}{c}\text { Bio-SPK } \\
{[18]}\end{array}$ & 8 & First-of-a-kind commercial \\
\hline
\end{tabular}

\section{A proposal for a technology ranking}

The status and the reliability of the technologies in the advanced biofuels sector depend on several factors. In this study, some of those are discussed with the aim to select the most promising technologies.

The biofuel quality plays a significative role in the ranking process, since it is responsible in determining affordability in the market development. This parameter, in turn, is affected by the following items: number of processing steps, being drop-in fuels, production and feedstock costs and availability. Indeed, a higher number of steps per process makes the supply chain complex and expensive, while a liquid biofuel which is drop-in is an added value since it is fully compatible with the existing petroleum infrastructures as reported in [22]. Similarly, feedstock and production costs, expressed in EUR/MWh, strongly influence the final biofuel ranking as they should satisfy the growing demand of the advanced biofuels in the current and future market. A score between 1 and 3 is assigned to each of these 
items, assuming 1 as a poor, 2 as a medium-good and 3 as a very good qualitative level as illustrated in Table 6.

Table 6. Biofuel quality level for liquid biofuels.

\begin{tabular}{|c|c|c|c|c|c|}
\hline Liquid biofuel & $\begin{array}{c}\mathbf{N}^{\circ} \text { of processing } \\
\text { steps }\end{array}$ & Drop-in fuel & $\begin{array}{c}\text { Feedstock } \\
\text { cost }\end{array}$ & $\begin{array}{c}\text { Biofuel } \\
\text { cost }\end{array}$ & Sum \\
\hline First generation bioethanol & 3 & 1 & 3 & 3 & 10 \\
\hline Second generation bioethanol & 1 & 1 & 3 & 1 & 6 \\
\hline First generation biodiesel & 3 & 2 & 2 & 2 & 9 \\
\hline Second generation biodiesel & 3 & 2 & 2 & 1 & 8 \\
\hline Third generation biodiesel & 3 & 2 & 2 & 1 & 8 \\
\hline Renewable diesel & 2 & 3 & 2 & 1 & 8 \\
\hline Green jet fuel & 1 & 3 & 1 & 3 & 8 \\
\hline Pyrolysys bio-oil & 3 & 1 & 3 & 1 & 8 \\
\hline Drop-in biofuel & 1 & 3 & 2 & 1 & 7 \\
\hline
\end{tabular}

Thus, Table 6 shows that the second-generation biofuels with the highest scores are in the range of biodiesel fuels. Once defined the biofuel quality, there are other parameters to be considered directly in the technology ranking as: TRL, feedstocks availability, production and feedstocks costs.

As previously illustrated in Table 5, the technologies with the highest TRL are fermentation for conventional ethanol, HVO/HEFA, anaerobic digestion for biogas and transesterification from vegetable oils for biodiesel. However, although all the technologies are mature, only the last four are significant for the advanced biofuels production. With reference to these technologies, feedstock and production costs (as reported in [14]), are summarized on average in the following Table 7, showing the lowest costs for biogas production and comparable values for the alternatives considered biofuels.

Table 7. Technologies with the highest TRL.

\begin{tabular}{|c|c|c|c|}
\hline TRL 9 Technologies & $\begin{array}{c}\text { Feedstock cost } \\
\text { [EUR/MWh] }\end{array}$ & $\begin{array}{c}\text { Production cost } \\
\text { [EUR/MWh] }\end{array}$ & $\begin{array}{l}\text { Total } \\
\text { [EUR/MWh] }\end{array}$ \\
\hline HVO or HEFA & 50 & 78 & 128 \\
\hline Anaerobic Digestion & 18.5 & 80 & 98.5 \\
\hline Transesterification from vegetable oil & 60 & 95 & 155 \\
\hline
\end{tabular}

\section{Conclusions}

From the analysis previously carried out, it is evident that HVO or HEFA represent a very convenient technology in terms of cost items for producing liquid advanced biofuels, while anaerobic digestion has to be preferred to produce biogas. As previously mentioned, the estimation of the current feedstocks' availability is based on conservative hypothesis to provide a resource-based assessment, which considers all possible constraints and other competitive uses. We showed that the most available feedstocks are agricultural residues, followed by wastes and vegetable oils, of which almost one million tons are free fatty acids. Therefore, from this analysis, we concluded that the optimal solution is to process vegetable oils via HVO to produce green diesel fuel, due to lower feedstock and production costs of a very mature technology, as well as the large availability of vegetable oils in the European 
Countries. However, a number of interesting alternatives with growing TRL value were considered and it is expected that they will become popular in the mid-term.

\section{References}

1. https://eur-lex.europa.eu/legal-content/EN/TXT/?uri=OJ:L:2018:328:TOC

2. https://www.mise.gov.it/index.php/it/energia/energia-e-clima-2030 [in italian]

3. https://www.iea.org/reports/transport-biofuels

4. https://ec.europa.eu/research/participants/data/ref/h2020/wp/2014_2015/annexes/h2020-wp1415-annex-g-trl en.pdf

5. Searle, S.Y., Malins, C. J., Waste and residue availability for advanced biofuel production in EU Member States, Elsevier, 2016, Biomass and Bioenergy, vol. 89, p. 2-10

6. EUROSTAT. Environment and energy, Environment, Waste, Treatment of waste Disposal Landfill and other (Data update to 2016) available on https://appsso.eurostat.ec.europa.eu/nui/show.do?dataset=env wastrt\&lang=en

7. DIRECTIVE 2008/98/EC OF THE EUROPEAN PARLIAMENT AND OF THE COUNCIL of 19 November 2008 on waste and repealing certain Directives available on https://eur-lex.europa.eu/legal-content/EN/TXT/PDF/?uri=CELEX:32008L0098\&from=EN

8. FAOSTAT. Vegetable Oils + (Total), CROPS, Production Quantity (Data update to 2018) available on http://www.fao.org/faostat/en/?\#data/BC

9. Bergsma, G., Kampman, B., Croezen, H., Sevenster, M., Biofuels and their global influence on land availability for agriculture and nature A first evaluation and a proposal for further fact finding, Delft, CE, 2007.

10. Canakci, M., Van Gerpen, J., Biodiesel production from oils and fats with high free fatty acids, American Society of Agricultural Engineers, 2001.

11. FAOSTAT. CROPS, Production Quantity (Data calculated on average between 2014 and 2018 available on http://www.fao.org/faostat/en/\#data/QC

12. FAOSTAT. Forestry Production and Trade, Production Quantity, coniferous, non-coniferous (Data calculated on average between 2014 and 2018) available on http://www.fao.org/faostat/en/\#data/FO

13. Searle, S.Y., Malins, C. J., Availability of cellulosic residues and wastes in the EU, International Council on Clean Transportation (ICCT), White Paper, 2013.

14. Brown, A., Waldheim, L., Landälv, I., Saddler, J., Ebadian, M., McMillan, J.D., Bonomi, A., Klein, B., Advanced Biofuels - Potential for Cost Reduction, IEA Bioenergy, 2020.

15. Müller-Langer, F., Majer, S., O’Keeffe, S., Benchmarking biofuels - a comparison of technical, economic and environmental indicators, Energy, Sustainability and Society, 2014.

16. Study on impacts of EU actions supporting the development of renewable energy technologies available on https://ec.europa.eu/research/energy/pdf/impacts_studies/study solar_pv.pdf

17. Jansen, R.S., Second Generation Biofuels and Biomass: Essential Guide for Investors, Scientists and Decision Makers, ch. 16, Wiley-VCH Verlag GmbH \& Co. KGaA, 2013.

18. Guo, M., Song, W., The growing U.S. bioeconomy: Drivers, development and constraints, ELSEVIER, 2019. 
19. Alberts, G., Ayuso, M., Bauen, A., Boshell, F., Chudziak, C., Gebauer, J.P., German, L., Kaltschmitt, M., Nattrass, L., Ripken, R., Robson, P., Taylor, R., Wagner, H., Innovation Outlook advanced liquid biofuels, IRENA, 2016.

20. Prussi, M., O'Connell, A., Lonzab, L., Analysis of current aviation biofuel technical production potential in EU28, ELSEVIER, 2019.

21. Jarvis, S.M., Samsatli, S., Technologies and infrastructures underpinning future $\mathrm{CO} 2$ value chains: A comprehensive review and comparative analysis, ELSEVIER, 2018.

22. Van Dyk, S., Su, J., McMillan, J. D., Saddler, J. N., 'DROP-IN' BIOFUELS: The key role that co-processing will play in its production, IEA Bioenergy, 2019.

23. Catalogue of bioeconomy solutions: Finding key information of promising bioeconomy solutions available on https://power4bio.draxis.gr/\#/. 